\title{
14
}

\section{Australia's Shrinking Advantages: How Technology Might Defeat Geography}

\author{
Andrew Davies
}

For many decades Australia's defence strategy has rested on three comparative advantages, sometimes explicitly stated and sometimes implicit. ${ }^{1}$ First, that its strategic geography provides Australia with a significant buffer against hostile power projection. Second, that Australia's alliance with the United States provides a high level of conventional and nuclear deterrence to would-be adversaries. And third, that Australia's armed forces enjoy a significant technological advantage over those of regional nations. But economic, geopolitical and technological evolutions have diminished those comparative advantages, especially in the past decade, and the next generation of theatre and global-range weapons will only continue the trend. Australia's current strategic settings and force structure are likely to require some significant rethinking.

Australian defence planning, at least in terms of the resources allocated, has long focused on the maintenance of a 'balanced force', centred on sophisticated but traditional land, sea and air platforms. In fact, the Australian Defence Force (ADF) of today bears a striking resemblance to the force developed by the Menzies government in the 1960s.

\footnotetext{
1 This chapter updates and expands upon previous work the author produced for the Australian Strategic Policy Institute, including some collaborative work with Benjamin Schreer.
} 
For much of the intervening period, that has been adequate, but, as recent Australian Government white paper assessments have noted, the strategic environment is changing for the worse. New military technologies are available to regional nations and the military power of the People's Republic of China is steadily growing. Cyberspace is already a highly contested area and allows remote attacks on Australia's military and national systems. The emergence of hypersonic strike weapons, some of which are likely to enter service this decade, will greatly reduce the safety bestowed by distance from North Asian power competitions for Australian and allied forces. It is also possible that we will see the weaponising of orbital space.

Australia's comfortable defence assumptions of the past few decades will not pertain in the future. This paper explores some of the possible impacts of new technologies on Australian defence planning and implications for the US alliance.

\section{Geography and Australia's Links to the US}

In defence planning, Australia has both benefited and suffered from its geography. Scale is a disadvantage for a nation with only the resources of a small population that has to defend across continental distances and police its jurisdiction over 10 per cent of the Earth's oceans. For example, a routine transit between fleet bases at Sydney and Fremantle represents a lengthy voyage for many European navies. Because of that, the ADF has to be structured as an expeditionary force even if the operational focus is limited to local operations.

But the huge distances of the Pacific theatre have also worked heavily in Australia's favour in the past, in two different but complementary ways: its long approaches complicate adversary logistic planning, and its location is a useful secure base for operations further afield. During World War II, imperial Japan was unable to muster the capability to project power across a hemisphere to overwhelm Australia, despite having swept through South-East Asia with few difficulties. In those days of industrial warfare, when massed forces were required to deliver a strategic effect, Australia was distant enough from Japan's centres of power to mean that an invasion was never seriously considered. The air attacks that did take place, from land bases in the archipelago supplemented by the occasional 
foray from naval aircraft, amounted to little more than nuisance value, being much less intense than air attacks in the European theatre or in those parts of Asia where forces could be concentrated at ranges suited to the platforms of the day.

Precisely because of the strategic sanctuary provided by its geographical separation from the centres of power in North Asia, Australia has long been seen by strategists in the US as an important staging point for its own strategic projection capability. In 1911, naval strategist Alfred Thayer Mahan wrote that the sea lines of communication between a rapidly developing west coast of North America and Australia would give the US a foothold even when Asian powers (particularly Japan after its defeat of Russia in 1905) held sway further north:

The Western Pacific will remain Asiatic, as it should ... The question awaiting and approaching solution is the line of demarcation between the Asiatic and European elements in the Pacific. The considerations advanced appear to indicate that it will be that joining Puget Sound and Vancouver with Australia..

Mahan's assessment was vindicated in the first year of the Pacific War. When planning for the war against Japan after the initial setbacks at Pearl Harbor and the Philippines, the US Joint Chiefs of Staff came to the conclusion that the:

Entire Allied strategy in the Pacific depended on two cardinal points: Hawaii must not fall, and Australia must not fall ... the new Pacific Fleet chief, Admiral Nimitz, [was ordered] to secure the seaways between Midway, Hawaii and the North American mainland. That was to be his first priority. The second, in only a 'small degree less important' was to protect the lifeline between North America and Australia ... By those means the allied war machine would be built up in Australasia. ${ }^{3}$

Australia's geography again offered advantages to the US during the Cold War, though this time the attraction was more to do with the ability to extend the US and Five Eyes' global command, control, communications, computers, intelligence, surveillance and reconnaissance (C4ISR) capability, manifested in joint facilities located on Australian soil.

2 A.T. Mahan, 'The Panama Canal and Sea Power in the Pacific', Century Magazine, June 1911. Reprinted in Armaments and Arbitration (New York: Garland Publishing, 1972).

3 Ian W. Toll, Pacific Crucible: War at Sea in the Pacific 1941-42 (New York: W. W. Norton \& Co., 2012), 182. 
In the absence of a credible regional peer adversary, the US Navy had virtually free rein in the Western Pacific after the Vietnam War. In that environment, Australia's defence outlook was benign. With the possible exception of Singapore, Australia fielded the most sophisticated military forces in the region and faced no potential adversaries with effective power projection capabilities.

But that was a somewhat artificial situation in the immediate aftermath of World War II and the post-colonial upheavals that followed. Because Asian economies enjoyed a period of high average economic growth and much greater internal stability (with a few exceptions) from the 1990s on, the region could afford militaries with modern platforms and capabilities, including air and maritime forces providing power projection beyond borders, rather than predominantly inwardly focused land forces.

Pre-eminent among Asia's resurgent military capability is China. The People's Liberation Army (PLA) has developed a formidablelooking-though untested in practice-anti-access/area denial (A2/ $\mathrm{AD})$ posture, and is now starting in earnest to develop a blue water power projection capability centred on aircraft carrier task groups and nuclear-powered submarines. China's $\mathrm{A} 2 / \mathrm{AD}$ posture is designed to keep foreign powers, especially the US, at a distance. As a result, today's power relativities resemble the Asia that Mahan saw when looking west a century ago. Though not yet the case, it is now conceivable that Washington will, in the future, come to judge that the Western Pacific will again be 'Asiatic' rather than its own sphere of influence.

A corollary is that the more contested space of North Asia has once again raised the value of Australia's geographical position in the eyes of its major ally. A 2015 joint study by The Australian National University's Strategic and Defence Studies Centre and the Center for Strategic and International Studies (CSIS) observed that:

Australia's geographic location is more important to the United States today than it has been at any time since the Second World War. Australia serves both as a link between the Indian and Pacific Oceans and as a sanctuary from China's anti-access/area denial capabilities. ${ }^{4}$

4 Michael J. Green, Peter J. Dean, Brendan Taylor and Zack Cooper, The ANZUS Alliance in an Ascending Asia, SDSC Centre of Gravity series, July 2015, sdsc.bellschool.anu.edu.au/sites/default/ files/publications/attachments/2015-12/COG_\%2323_Web_4.pdf. 
That conclusion is supported by an analysis of China's missile capabilities by the Missile Defense Project at CSIS. The number, type and range of Chinese missiles based along its coastline, including ballistic and cruise missile systems, provide effective coverage of its maritime approaches as far as the east coast of Japan. Beyond that, hundreds of medium-range ballistic missiles cover much of the South China Sea and Indonesia as far south as Jakarta. ${ }^{5}$ Submarine-launched weapons or launchers forward deployed on features in the South China Sea effectively extend that range to cover Australia's northern approaches.

The enduring presence of one or more Western powers in its strategic approaches is an affront to the Chinese Government-the 'century of humiliation' at the hands of Western powers looms large in Chinese strategic thinking. Consequently, Beijing is serious about its intentions to be able to deny its extended approaches to what it termed in its 2008 defence white paper 'strategic manoeuvres and containment from the outside' (a phrase echoed many times since). ${ }^{6}$ In fact, the Chinese military first articulated 'active off-shore defense' as PLA Navy doctrine in 1985. ${ }^{7}$ Decades of consistent double-digit GDP growth have allowed it to manifest that concept as a force in being.

The US has a few possible responses. It can double down on its posture and harden its forward-deployed forces within range of Chinese weapons, it can pull back at least some of those forces to safer locations or it can cede strategic ground to China. In practice, it has done a little of all those, while developing new concepts for operations in an A2/AD environment, such as the 'Air-Sea Battle Concept' and its subsequent evolutions. ${ }^{8}$ Not surprisingly, an increased presence in Australia-though only modest so far-has featured in some recent US force posture initiatives. A greater footprint in Australia is a rational response to the growth in China's power projection and strike capabilities over the past 20 years. If nothing else, keeping beyond the range of the many short to medium-range weapons greatly reduces the chance of a debilitating strike in the early stages of a conflict.

5 Missile Defense Project, 'Missiles of China', Missile Threat, Center for Strategic and International Studies, 14 June 2018, missilethreat.csis.org/country/china/.

6 China's National Defense in 2008, Information Office of the State Council of the People's Republic of China, 20 January 2009, www.china.org.cn/government/whitepaper/node_7060059.htm.

7 Alexander Chieh-cheng Huang, 'The Chinese Navy's Offshore Active Defense Strategy: Conceptualization and Implications', Naval War College Review 47(3), 1994, 7-32.

8 Jan van Tol, Mark Gunzinger, Andrew F. Krepinevich and Jim Thomas, 'AirSea Battle: A Point-of-Departure Operational Concept', Center for Strategic and Budgetary Assessments, 18 May 2010, csbaonline.org/research/publications/airsea-battle-concept. 
From an Australian perspective, providing a safe harbour for US forces also bolsters our own position, as any hostility projected towards Australia would necessarily engage the US as well. As it has done in the past, the strategic geography of the region has pushed Australian and US interests together. However, it is not clear that the current advantages are sustainable. For reasons explained below, today's alliance posture may be at best meta-stable, and the refuge provided by geography might not be as enduring as we hope. Developments in technology continue to effectively shrink the world, while national interests and vulnerabilities in cyberspace and space transcend terrestrial geography.

\section{The Future-Australia's Defence in a Shrinking World}

The above discussion is very much couched in terms of traditional military platforms such as ships, submarines and aircraft. If the only defence problems were the protection of territory and sea lines of communication, as was the case during industrial-age warfare, that might be an adequate view. But today's world also places a high value on information, making cyberspace an important arena of competition between nations.

There is no doubt that attacks in cyberspace can be extremely damaging, as Estonia's experience in 2007 showed. But defence against cyber attack is also possible, and arguably the window of early opportunities to exploit and attack underprepared national-level cyber architecture has largely closed (though the wider economy is likely still vulnerable). While some once talked up the possibility of a hugely damaging cyber strike-a 'cyber Pearl Harbor' in the language of former US Secretary of Defense Leon Panetta' —others argued against such a dramatic take, suggesting that cyber activities are a new manifestation of the age-old practices of espionage, subversion and sabotage. ${ }^{10}$ The latter view is consistent with the observations of constant background cyber activity, including espionage, the probing of systems and the conduct of information operations (such as Russia's manipulation of a section of the US public during the 2016 presidential election). That said, the lack of an example

9 Leon E. Panetta, 'Remarks by Secretary Panetta on Cybersecurity to the Business Executives for National Security', New York City, 11 October 2012, www.hsdl.org/?view\&did=724128.

10 Thomas Rid, 'Cyber War Will Not Take Place', Journal of Strategic Studies 35(1), 2012, 5-32, doi.org/10.1080/01402390.2011.608939. 
of a massive and dramatically damaging cyber strike is not necessarily comforting; the successful erosion of democratic norms is potentially as damaging to Western states in the longer term. While Australia and the US have similar interests in minimising the harm done by hostile actors in cyberspace, geography does nothing to help against such attacks.

More pertinently for questions of hard defence, it seems increasingly possible that there will be a significant weaponisation of space in the next couple of decades. Space has been an arena for communications, intelligence gathering and surveillance activities since the 1960s. The advantages of hosting ground stations in Australia have been a net positive for Australia in providing value to the US. To date, space has not been a potential source of conventional kinetic strikes. But that could change; though the deployment of nuclear weapons in orbit has long been outlawed by treaty, several nations are developing a new generation of conventionally armed, global-range hypersonic strike weapons, some of which could be pre-deployed in orbit. ${ }^{11}$

There are two broad classes of hypersonic weapon systems of relevance to the discussion here: vehicles that re-enter from orbit and air-breathing cruise missiles. ${ }^{12}$ As an example of the former, the Pentagon's research and development program includes a 'common glide vehicle'-a hypersonic re-entry vehicle-at the centre of its conventional prompt global strike program. ${ }^{13}$ The aim of the program, as the name suggests, is to provide the US with the capability of rapidly delivering conventional weapons anywhere on Earth-within tens of minutes. Hypersonic glide vehicles could be either first boosted into orbit from terrestrial launchers before re-entry or pre-deployed in orbit to provide a shorter response time. They are intended to augment existing conventional strike capabilities that require launch platforms to first manoeuvre within firing range, and thus potentially be exposed to A2/AD systems. As well, ephemeral mobile

11 Treaty on Principles Governing the Activities of States in the Exploration and Use of Outer Space, including the Moon and Other Celestial Bodies, United Nations Res. 2222 (XXI), 1966, www.unoosa. org/oosa/en/ourwork/spacelaw/treaties/outerspacetreaty.html.

12 For an overview of hypersonic systems and some of the strategic issues they raise, see Andrew Davies, 'Coming Ready or Not: Hypersonic Weapons', Australian Strategic Policy Institute, 23 March 2021, www.aspi.org.au/report/coming-ready-or-not-hypersonic-weapons.

13 Conventional Prompt Global Strike and Long-Range Ballistic Missiles: Background and Issues (Washington: Congressional Research Service, 14 February 2020), crsreports.congress.gov/product/ $\mathrm{pdf} / \mathrm{R} / \mathrm{R} 41464$. 
targets such as road-mobile launchers have proven extremely difficult to effectively target in the past. Prompt-strike capabilities that shrink the time between detection and a weapon on target offer a possible remedy.

The US has no monopoly on such systems and, in fact, may lag behind others in some respects. Russian leader Vladimir Putin has boasted of Russian systems with global capabilities-though it is not clear how seriously to take some of his wilder claims, such as a global-range nuclear-powered weapon. China has also been active in developing hypersonic glide vehicles, including integrating them on to its existing ballistic missile launchers. ${ }^{14}$ Chinese weapons are perhaps of more immediate concern for Australia's defence planning, although truly global strike capabilities mean that vital US C4ISR facilities located in Australia could be targeted early in a European conflict, for example.

In a different category, hypersonic cruise weapons offer fast strike capabilities over similar ranges to short and intermediate-range ballistic missiles-between 500 and 5,000 kilometres. According to a study by the Center for Strategic Budgetary Assessment in Washington, intermediate-range hypersonic glide or cruise weapons are competitive with intermediate-range ballistic missiles in both range and expected development cost. They also potentially offer better capability, being harder to detect and more manoeuvrable, so they travel on less predictable trajectories in the terminal phase and can approach targets from multiple directions. ${ }^{15}$ Again, the US is only one of several active players in the area, and many observers expect operational hypersonic cruise weapons to be fielded by China, Russia and the US before the decade is out. There are considerable strategic destabilisation risks that come with those developments; they raise (and sometimes exacerbate) the same issues that led to the negotiation of the Intermediate-Range Nuclear Forces Treaty during the latter stages of the Cold War. The US Congressional Research Service has suggested that treaty arrangements

14 Mike Yeo et al., 'Hypersonic and Directed-Energy Weapons: Who Has Them, and Who's Winning the Race in the Asia-Pacific?', Defense News, 15 March 2021, www.defensenews.com/ global/asia-pacific/2021/03/15/hypersonic-and-directed-energy-weapons-who-has-them-and-whoswinning-the-race-in-the-asia-pacificl.

15 Jacob Cohn et al., 'Leveling the Playing Field: Reintroducing US Theatre-Range Missiles in a Post-INF World', Center for Strategic and Budgetary Assessments, 19 May 2019, csbaonline.org/ research/publications/leveling-the-playing-field-reintroducing-us-theater-range-missiles-in-a-postINF-world. 
to deal with hypersonic weapons might be desirable to help manage the escalatory issues that could arise, but there seems to be little enthusiasm for such discussions.

Weapons with ranges of 2,000 kilometres or more deployed as part of China's $\mathrm{A} 2 / \mathrm{AD}$ force posture would effectively negate the buffer of distance for bases and facilities in the north of Australia. Prompt global strike weapons would almost negate the advantages of geography entirely. For the ADF there would be one upside to the availability of such weapons, given that it has lacked the ability to strike targets at distances much beyond 500 kilometres since the retirement of the F-111 bomber. Intermediate-range hypersonic cruise weapons might prove attractive as a way to reinstate that capability. But even that would need careful consideration. The strategic need that drove the 1960s decision to acquire the F-111 was the risk of aggression from Indonesia, to be countered by the ability to strike targets as far away as Jakarta, with no Indonesian capability of responding in kind. Today's environment is quite different, and the logic of a technological imbalance between Australia and Indonesia simply does not apply to China. If Australia (either with or without US cooperation) was to pursue an intermediate-range strike capability as part of a deterrence posture, China could respond in kind and forward deploy its own systems - perhaps to the South China Sea-to be able to rapidly strike Australian targets. A widespread proliferation of hypersonic weapons (or even intermediate-range ballistic weapons) would go a long way to eroding Australia’s geographical advantage.

For much of the second half of the twentieth century, the prevailing military paradigm was that territorial integrity was by far the most vital interest to be protected through military force. Australia's defence planners have long been able to take comfort in the fact that force projection against the nation is formidably difficult due to the distances involved. And that calculus improves when augmented by a major power alliance that raises the stakes even higher for a would-be adversary. Not that there was much power projection capability — or even much in the way of sophisticated forces of any kind - to worry about in Australia's part of the world until recently. The net result is an ADF that has long been centred on a small number of high-performance (and expensive) platforms. It is a force designed to deal with any likely threat from South-East Asia, run 
independent operations in its local neighbourhood and have enough expeditionary capability to make real contributions to coalition operations with its major ally, the US.

The days in which that was enough, and the right type of, capability are rapidly coming to an end. US hegemony has been good for Australia, but it is now coming under challenge. Technological advantages are being rapidly eroded - and may not exist at all in some strategically important emerging technologies. We are currently in a transition period between US dominance and the US having to contemplate operating against a near-peer adversary in the Pacific theatre-a situation it has not experienced for 80 years. Australia's value to the Australia, New Zealand, United States Security Treaty (ANZUS) alliance depends in part on geography, and Australia's location and geographical separation from North Asia still provide some natural advantages. But, like the technological gap, those advantages are diminishing. In the absence of international conventions that limit the proliferation of new weapon technologies, the ability for an adversary to strike at Australia's core military capabilities and national infrastructure will increase markedly. It is possible that Australia will be able to establish a sort of détente, possibly by deploying similar systems itself, and probably in cooperation with the US. But, at best, it will certainly require some different thinking about the way in which Australia approaches its defence planning. At worst, it may also significantly diminish the geographic value that Australia has had for its main ally. 
This text is taken from Alliances, Nuclear Weapons and Escalation: Managing Deterrence in the 21st Century, edited by Stephan Frühling and Andrew O'Neil, published 2021 by ANU Press, The Australian National University, Canberra, Australia.

doi.org/10.22459/ANWE.2021.14 